\title{
Seasonal Home Ranges and Activity of Small Mammals of a Colorado Subalpine Forest
}

\author{
Joseph F. MERRITT \& Joanie M. MERRITT
}

\begin{abstract}
Merritt J. F. \& Merritt J. M., 1978: Seasonal home ranges and activity of small mammals of a Colorado subalpine forest. Acta theriol., 23, 9: 195-202 [With 2 Tables].

Small mammals were live-trapped for 16 months on a $12 \times 12$ study grid (1.2 ha.) located in a subalpine forest on the Eastern Slope of the Colorado Rocky Mountains at an elevation of $3,120 \mathrm{~m}$. Snow covered the ground for $7^{1 / 2}$ months of the year. Subnivean activity of Clethrionomys gapperi and Peromyscus maniculatus was monitored by use of live-traps located within trap chimneys. Home ranges were measured during summer and winter. In the latter, movements of mice were restricted to the subnivean environment. No significant differences in home ranges were found within species during winter and summer. Winter trapped deermice exhibited slightly smaller mean home ranges than voles for the same period. Mean home ranges of $P$. maniculatus trapped in summer were significantly larger than those of $C$. gapperi from the same period. During mid-winter, P. maniculatus showed low trappability. This was thought to be due to a short-term torpor, aggregation of animals into small nesting groups and the comparatively reduced size of winter home ranges. It was suggested that these three factors were adaptive in conserving energy during winter months.
\end{abstract}

[Dept. Biol. Sci., Old Dominion Univ., Norfolk, Virginia 23508, USA].

\section{INTRODUCTION}

Although a good deal of work was published on the home range dynamics of $C$. gapperi and $P$. maniculatus, it was limited to geographic areas which exhibited little or no snow during winter months. The study reported herein, conducted from January 1974 to September 1975, attempted to determine the effect of a continuous blanket of snow on seasonal movements and activity of these two small mammals.

The research was conducted in Roosevelt National Forest, adjacent to the University of Colorado Mountain Research Station, NW 1/4 Sec. 22, $\mathrm{T} 1 \mathrm{~N}, \mathrm{R} 73 \mathrm{~W}$, at an elevation of approximately $3,120 \mathrm{~m}$. The study plot, dominated by Engelmann spruce (Picea engelmannii) and subalpine fir (Abies lasiocarpa), was oriented northwest-southeast and was bisected by a creek. A few limber pines (Pinus flexilis) and lodgepole pines (Pinus contorta) grew in the stand. The lower synusia consisted primarily of myrtle blueberry (Vaccinium myrtillus). The region is cha- 
racterized by a continental climate. On the study plot, snow covered the ground for about $7 \frac{1}{2}$ months. Snow accumulation began in early November 1974 and mice established subnivean runway systems by early to mid-December - snow depth ranged from $25-30 \mathrm{~cm}$. at this time. During winter months, the mean temperature recorded in the subnivean runway was $0^{\circ} \mathrm{C}$ with little fluctuation. In mid-February mean snow depth was about $100 \mathrm{~cm}$. Snow accumulation was greatest during April and May 1975, reaching $270 \mathrm{~cm}$. in areas of drifting snow. Snow ablation began in early June 1975, and mice abandoned subnivean runways by the end of the month. A detailed description of climate, vegetation and geology of the study area is provided by Merrit: (1976). The study area consisted of a $12 \times 12$ grid of stations at $10-\mathrm{m}$. intervals, occupying an area of 1.2 ha. A total of 144 stations (two traps per station) was monitored twice daily. There were two trapping periods per month, each consisting of one day prebaiting and three days trapping.

\section{MATERIAL AND METHODS}

Subnivean activity of mice was monitored by use of trap chimneys constructed of a double thickness of \#90 roofing paper with one chimney positioned at each station on the quadrat. Chimneys were cylindrical, about $90 \times 25 \mathrm{~cm}$. in size and placed at ground level. Two entrances were cut in the bottom of the chimney so that mammals could enter the chamber where two small Sherman live-traps were housed (Merritt, 1976). Mice were marked for identification by toe clipping. Each time a mouse was captured, toe clip number, location on grid, weight, sex, and reproductive status were recorded. Animals were weighed to the nearest $0.5 \mathrm{~g}$. using a Pesola scale, and classified as adult, subadult or juvenile according to body weight.

In the present study, we have chosen to utilize the inclusive boundary strip method (Stickel, 1954), because it facilitates comparisons between species and between results of different workers dealing with the same species. Data obtained from live-trapping were used to plot home ranges. Movements were followed year-round and periods of snow-covered and snow-free substrate were considered separately. For calculation of home range, a minimum of three recaptures was required to reduce the chance of including transients as part of the resident population.

\section{RESULTS AND DISCUSSION}

Table 1 shows average home ranges for male and female C. gapperi and $P$. maniculatus trapped from snow-free (summer) and snow-covered (winter) substrates. During winter and summer, mean home ranges of male and female $C$. gapperi were the same. The average subnivean home range of voles tended to be larger than the average non-subnivean. In 
contrast, home ranges of Peromyscus trapped below the snow were smaller than those calculated for the snow-free period. Male P. maniculatus exhibited a larger winter and summer home range than did females. No significant differences $(p<0.05)$ were found between home ranges within species using Student's $t$ tests. However, average home ranges of deermice trapped in summer were significantly larger than those of voles for the same period. Winter trapped deermice exhibited a slightly smaller mean home range than voles for the same period, but this difference was not significant. A very large range was found

Table 1

Mean home range of adult Clethrionomys gapperi and Peromyscus maniculatus captured from snow-covered (winter) and snow-free (summer) substrates. Calculations are based on inclusive boundary strip method. Figures in parentheses are range of movements.

\begin{tabular}{|c|c|c|c|c|c|c|}
\hline & Snow-covered & Substrate & (wintér) & Snow-free & Substrate & (summer) \\
\hline Sex & $\begin{array}{l}\text { Area } \\
\text { (hectares) }\end{array}$ & S.E. & $\begin{array}{l}\text { Sample } \\
\text { Size }\end{array}$ & $\begin{array}{c}\text { Area } \\
\text { (hectares) }\end{array}$ & S.E. & $\begin{array}{c}\text { Sample } \\
\text { Size }\end{array}$ \\
\hline \multicolumn{7}{|c|}{ Clethrionomys gapperi } \\
\hline Male & $\begin{array}{c}0.02 \\
(0.003-0.05)\end{array}$ & 0.17 & 40 & $\begin{array}{c}0.01 \\
(0.002-0.06)\end{array}$ & 0.29 & 19 \\
\hline Female & $(0.004-0.05)$ & 0.18 & 22 & $\begin{array}{c}0.01 \\
(0.002-0.03)\end{array}$ & 0.17 & 19 \\
\hline \multicolumn{7}{|c|}{ Peromyscus maniculatus } \\
\hline Male & $\begin{array}{c}0.02 \\
(0.005-0.05)\end{array}$ & 1.02 & 5 & $\begin{array}{c}0.03 \\
(0.003-0.08)\end{array}$ & 0.54 & 18 \\
\hline Female & $\begin{array}{c}0.01 \\
(0.005-0.03)\end{array}$ & 0.36 & 5 & $\begin{array}{c}0.02 \\
(0.008-0.06)\end{array}$ & 0.55 & 9 \\
\hline
\end{tabular}

in the movements of both species; it did not appear that the number of captures and/or length of time an animal was caught accounted for this range.

Table 2 compares home ranges of $C$. gapperi and $P$. maniculatus determined in the present study with those of other workers. Studies dealing with the home range of these species have been limited to snow-free periods, with the exception of B e e r (1961) and the present study. Our results compare closely with those of Buts ch (1954) from a maple-basswood forest of Minnesota and those of Mor ris (1955) from a coniferous forest in New Brunswick. Other studies on C. gapperi showed generally larger home ranges and a tendency for males to exhibit a slightly larger home range than females (Table 2).

Peromyscus maniculatus in the present study showed significantly larger summer home ranges than $C$. gapperi. These ranges were smaller 


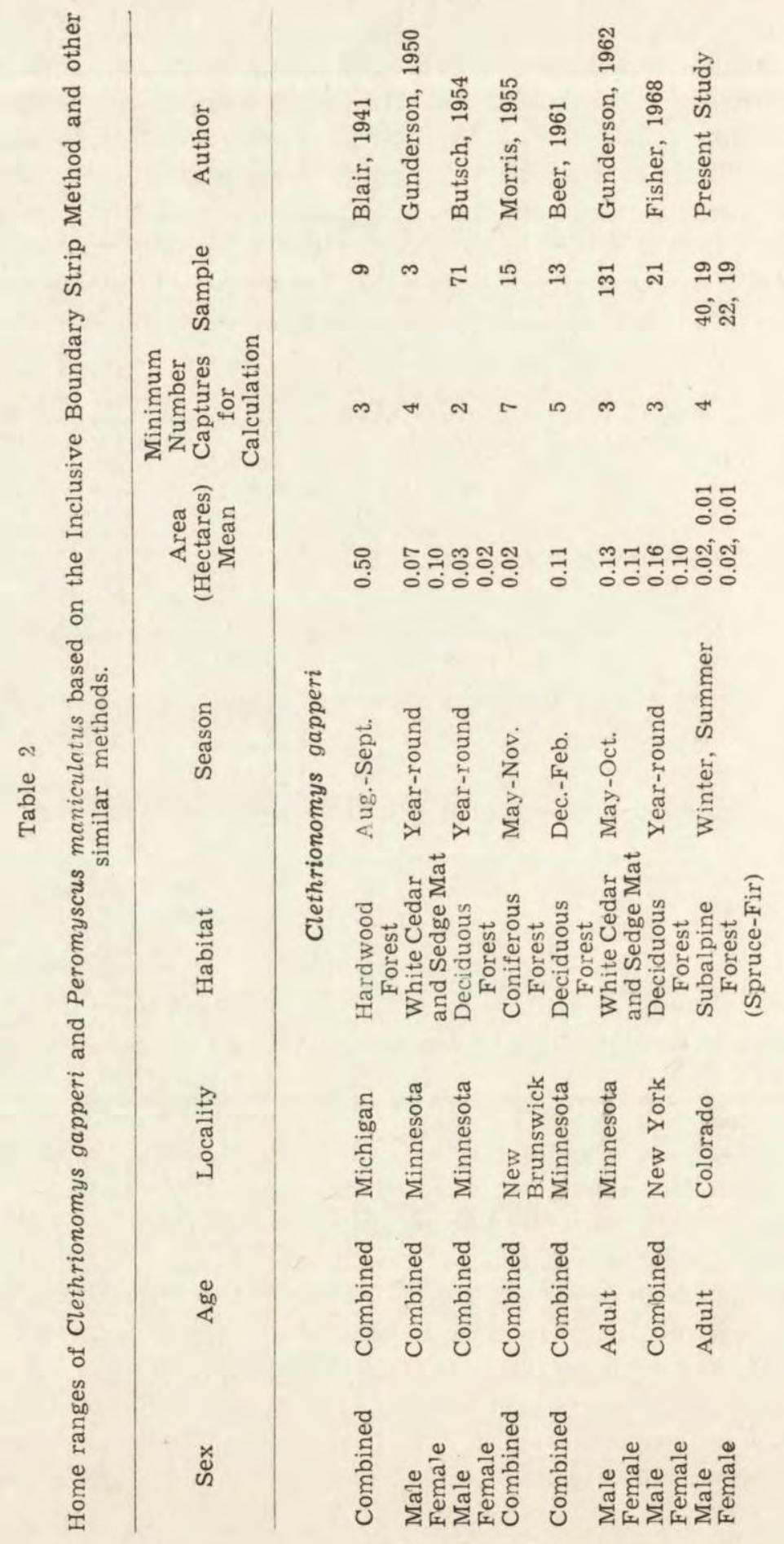




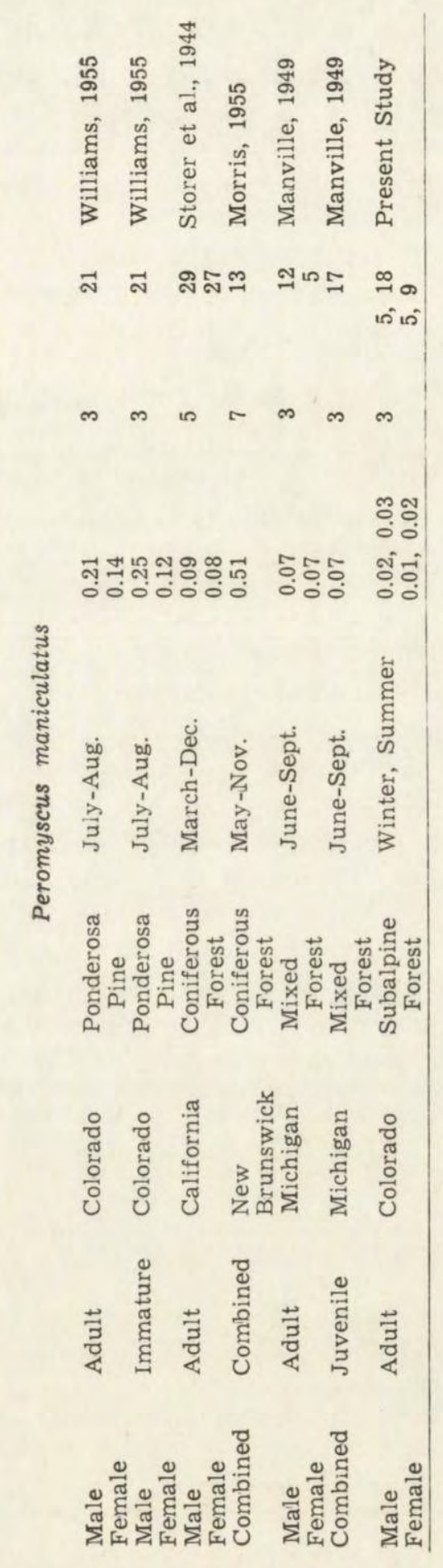


than those calculated for deermice from other forest situations (Table 2). Williams (1955) and Storer et al. (1944) indicated that male $P$. maniculatus exhibited a larger home range than females. Our data showed a similar relationship, but these differences were not significant.

Biologists working on winter dynamics of small mammals have indicated an inability to trap $P$. maniculatus. F u 11 e r et al. (1969) encountered low numbers of deermice and suggested that torpor occurred in response to reduced availability of seeds and berries in winter. Torpor was thought to account for low trappability of $P$. maniculatus in aspen and pine habitats of Minnesota (B rown, 1971) and in a subalpine "park " of Colorado (V a u g h a n, 1974). How a r d (1951) studied P. maniculatus in outdoor enclosures in Michigan and California and observed winter torpor due to cold weather and insufficient food supply. S t e b bin s (1968) observed periods of torpor in deermice which were caged alone and given food in excess, whereas Morhardt \& Hudson (1966) induced torpor by food deprivation. In the present study, many deermice marked in fall were not recaptured until spring or summer, indicating a possible winter torpor.

Another hypothesis for reduced trappability was proposed by $\mathrm{N}$ icholson (1941) and Thomsen (1945) working on P. leucopus in Michigan and Wisconsin respectively. They suggested that deermice aggregate into small groups during winter months. Aggregation and huddling of $P$. maniculatus was suggested by Howard (1951) and Brown (1971) as a means of reducing metabolic demands during winter. In the present work, evidence for group nesting was found on one occasion. In December, five $P$. maniculatus had gained access and established a nest in the supply box which housed bait for trapping.

In our study, it appeared that short-term torpor, aggregate nesting and reduced home ranges occurred during winter, resulting in low trappability. It is felt that these "strategies" are adaptive as energy conserving devices during harsh winter months. Additional research (under laboratory and field conditions) is necessary in order to more fully understand the behavior of small homeotherms inhabiting the subnivean environment.

\section{REFERENCES}

1. B e e r J. R., 1961: Winter home ranges of the red-backed mouse and whitefooted mouse. J. Mamm., 42: 174-180.

2. B la ir W. F., 1941: Some data on the home ranges and general life history of the short-tailed shrew, red-backed vole, and woodland jumping mouse in northern Michigan. Amer. Midl. Nat., 25: 681-685.

3. Brown E. G., III, 1971: Some aspects of the ecology of the small, winter-active 
mammals of a field and adjacent woods in Itasca State Park, Minnesota. $\mathrm{Ph}$. D. Thesis, Univ. Minnesota, $173 \mathrm{pp}$.

4. Butsch R., 1954: The life history and ecology of the red-backed vole; Clethrionomys gapperi gapperi Vigors, in Minnesota. Ph. D. Thesis, Univ. Michigan, $148 \mathrm{pp}$.

5. F is her R. L., 1968: An ecological study of the red-backed vole, Clethrionomys gapperi gapperi (Vigors), in central New York. Ph. D. Thesis, Cornell University, $79 \mathrm{pp}$.

6. Fuller W. A., Stebbins L. L. \& Dyke G. R., 1969: Overwintering of small mammals near Great Slave Lake, northern Canada. Arctic, 22: 34-55.

7. Gunderson H. L., 1950: A study of some small mammal populations at Cedar Creek Forest, Anoka County, Minnesota. Occ. Pap., Minn. Mus. Nat. Hist., 4: $1-49$.

8. Gunders on H. L., 1962: An eight and one-half year study of the red-backed vole (Clethrionomys gapperi Vigors) at Cedar Creek Forest, Anoka and Isanti Counties, Minnesota. Ph. D. Thesis, Univ. Michigan, $110 \mathrm{pp}$.

9. Howard W. E., 1951: Relation between low temperature and available food to survival of small rodents. J. Mamm., 32: $300-312$.

10. Manville R. H., 1949: A study of small mammal populations in northern Michigan. Mise. Publ., Univ. Michigan Mus. Zool., 73: 1-83.

11. Merritt J. F., 1976: Population ecology and energy relationships of small mammals of a Colorado subalpine forest. Ph. D. Thesis, Univ. Colorado, $133 \mathrm{pp}$.

12. Morhardt J. E. \& Hudson J. W., 1966: Daily torpor induced in whitefooted mice (Peromyscus spp.) by starvation. Nature, 212: 1046-1047.

13. Morris R. F., 1955: Population studies on some small forest mammals in eastern Canada. J. Mamm., 36: 21-35.

14. Nicholson A. J., 1941: The homes and social habits of the woodmouse (Peromyscus leucopus noveboracensis) in southern Michigan. Amer. Midl Nat., 25: $196-223$.

15. Stebbins L. L., 1968: Seasonal and latitudinal variations in circadian rhythms of three species of small rodents in northern Canada. Ph. D. Thesis, Univ. Alberta, Edmonton, 68 pp.

16. Stickel L. F., 1954: A comparison of certain methods of measuring ranges of small mammals. J. Mamm., 35: 1-15.

17. Storer T. I., Evan S F. C. \& Pa 1 mer F. G., 1944: Some rodent populations in the Sierra Nevada of California. Ecol. Monogr., 14: 165-192.

18. Thomsen H. P., 1945: The winter habits of the northern white-footed mouse. J. Mamm., 26: 138-142.

19. Vaughan T. A., 1974: Resource allocation in some sympatric, subalpine rodents. J. Mamm., 55: 764-795.

20. Williams O., 1955: Home range of Peromyscus maniculatus rufinus in: a Colorado ponderosa pine community. J. Mamm., 36: 42-45.

Accepted, September 25, 1977. 
Joseph F. MERRITT \& Joanie M. MERRITT

\section{AREAŁ OSOBNICZY I AKTYWNOSC DROBNYCH SSAKOW W SUBALPEJSKIM LESIE W COLORADO}

\section{Streszczenie}

Zbadano letni i zimowy areał osobniczy oraz aktywność Clethrionomys gapperi i Peromyscus maniculatus żyjących w subalpejskim lesie, polożonym na wschodnim skłonie Colorado Rocky Mountains, na wysokości $3120 \mathrm{~m}$. Pokrywa śnieżna w tym lesie utrzymuje się przez $7^{1 / 2}$ miesiąca. Odłowy prowadzono przez 16 miesięcy, na powierzchni 1,2 ha, stosując metodę CMR. Do kontroli aktywności podśnieżnej używano żywołówek połączonych z ułożonymi na powierzchni gruntu cylindrycznymi kanałami. Wielkość areału osobniczego w porównywanych sezonach nie różni się istotnie $\mathrm{w}$ obrębie gatunku. Zimą średni areał osobniczy $P$. maniculatus jest nieco mniejszy niż C. gapperi. Natomiast latem jest on istotnie większy u P. maniculatus (Tabela 1). W środku zimy $P$. maniculatus ma niską lowność, co można tłumaczyć krótkotrwałym odrętwieniem, łączeniem się zwierząt w male, wspólnie gnieżdżące się grupy oraz nieco zmniejszonym areałem osobniczym. Sugeruje się, że są to czynniki adaptatywne, umożliwiające zaoszczędzenie energii $\mathrm{w}$ warunkach zimy. 